\title{
Cytotoxic activity of some marine brown algae against cancer cell lines
}

\author{
MAHNAZ KHANAVI ${ }^{1}$, MARYAM NABAVI ${ }^{1}$, NARGESS SADATI ${ }^{1}$, \\ MOHAMMADREZA SHAMS ARDEKANI ${ }^{1}$, JELVE SOHRABIPOUR ${ }^{3}$, SEYED \\ MOHAMMAD B. NABAVI ${ }^{4}$, PADIDEH GHAELI $^{5}$ and SEYED NASSER OSTAD ${ }^{2}$
}

${ }^{1}$ Department of Pharmacognosy and Pharmaceutical Science Research Center, Faculty of Pharmacy, Tehran University of Medical Sciences, Tehran 14155-6451, Iran.

${ }^{2}$ Department of Toxicology \& Pharmacology and Pharmaceutical Science Research Center, Faculty of Pharmacy, Tehran University of Medical Sciences, Tehran 14155-6451, Iran.

${ }^{3}$ Agriculture and Natural Resource Research Center of Hormozgan. Bandar Abbas, 79145-1577, Iran.

${ }^{4}$ Khorramshahr University of Marine Science and Technology, Khuzestan, P. O. Box.661, Iran.

5 Psychiatry and Psychology Research Center, Roozbeh Psychiatric Hospital and Faculty of Pharmacy, Tehran University of Medical Sciences, Tehran 13337-95914, Iran.

\begin{abstract}
The aim of this study was to investigate the in vitro cytotoxic activity of total extract of $\mathrm{MeOH}(70 \%)$ and partition fractions of hexan, chloroform $\left(\mathrm{CHCL}_{3}\right.$, ethylacetate $(\mathrm{EtOAc})$ and $\mathrm{MeOH}-\mathrm{H}_{2} \mathrm{O}$ of brown algae species (Sargassum swartzii, Cystoseira myrica, Colpomenia sinuosa) found in the Persian Gulf against in different cell lines including HT-29, Caco-2, T47D, MDA-MB468 and NIH 3T3 cell lines by MTT and AnnexinV-PI assay. The hexan fraction of $S$. swartzii and $C$. myrica showed selective cytotoxicity against proliferation of Caco- 2 cells $\left(\mathrm{IC}_{50}<100 \mu \mathrm{g} / \mathrm{ml}\right)$ T47D cell line $\left(\mathrm{IC}_{50}<100 \mu \mathrm{g} / \mathrm{ml}\right)$, respectively. $S$. swartzii and C. myrica were also observed for increasing apoptosis in Caco-2 and T47D cells. Total extract and fractions of $C$. sinuosa did not show any significant cytotoxicity against the studied cell lines. MDA-MB468 cells were more sensitive to $C$. myrica than was T47D ( $\mathrm{IC}_{50} 99.9 \pm 8.11$ vs. $\left.56.50^{`} \pm 0.88\right)$. This reflects an estrogen receptor independent mechanism for cytotoxicity of the extract. The $\mathrm{IC}_{50}$ of the hexan fraction of $C$. myrica on T47D parent cells was lower than it was on T47D-TR cells $\left(I C_{50} 99.9 \pm 8.11\right.$ vs. $\left.143.15 \pm 7.80\right)$. This finding suggests a role for the MDR-1 in the development of possible future tolerance to the extract.
\end{abstract}

Key terms: Colpomenia sinuosa, Cystoseira myrica, Cytotoxic activity, MTT assay, Persian Gulf, Sargassum swartzii.

\section{INTRODUCTION}

Marine algae produce a wide range of new secondary metabolites with various biological activities (Mayer et al., 2007). In an attempt to find new anticancer drugs, most seaweeds, including the brown algae of genus Sargassum (Sargassaceae), $S$. micracanthum (Mori et al., 2005), S. caryophyllum (Tang et al., 2002) and $S$. tortile (Numata et al., 1991), have been examined for cytotoxicity. These species have exhibited cytotoxic activity against cancer cell lines. Cystoseira (Cystoseiraceae) is a widely distributed genus of brown algae (Amico, 1995) with antibacterial, antifungal, and cytotoxic activities (Bennamara et al., 1999; Abourriche et al., 1999; Ayyad et al., 2003).

The Iranian coast lines in the Persian Gulf and Oman Sea are about $1260 \mathrm{~km}$ long. Recent data has noted 153 species of marine algae from coast lines of Iranian islands and Hormozgan Province (Sohrabipour and Rabii, 1999 and Sohrabipour et al., 2004). However, there have been only a few studies on the pharmacological effects of the marine algae in this region. 
This study was designed to determine in vitro cytotoxic activity of the total $\mathrm{MeOH}$ (70\%) extract and partition fractions obtained from three species of brown algae from coastlines of the Persian Gulf in southern Iran.

\section{METHODS}

\section{Plant material}

Brown algae, Sargassum swartzii C. Agardh (Sargassaceae), Cystoseira myrica (S.G.Gmelin) C. Agardh (Cystoseiraceae), Colpomenia sinuosa (Mertens ex Roth) Derbès \& Solier (Scytosiphonaceae), were collected from the Asaluye-Niband Protected Marine Area of the Persian Gulf in June 2007. The algae were identified by J. Sohrabipour at the Agriculture and Natural Resource Research Center of Hormozgan, Iran. The voucher specimens were deposited at this center.

\section{Extraction and fractionation of marine algae}

The algae were air-dried in the shade, at room temperature, and ground to powder with a mortar and pestle. Fifty grams of each sample was extracted with Methanol- $\mathrm{H}_{2} \mathrm{O}$ (70:30) $(5 \times 200 \mathrm{ml})$ at room temperature. The combined extracts were evaporated under vacuum. The residues were successively partitioned between $\mathrm{MeOH}-\mathrm{H}_{2} \mathrm{O}$ (9:1) and hexan, $\mathrm{MeOH}-\mathrm{H}_{2} \mathrm{O}(8: 2)$ and $\mathrm{CHCL}_{3}, \mathrm{MeOH}-$ $\mathrm{H}_{2} \mathrm{O}$ (1:1) and EtOAc. Removal of the solvents resulted in the production of hexan, $\mathrm{CHCL}_{3}$, EtOAc and $\mathrm{MeOH}-\mathrm{H}_{2} \mathrm{O}$ fractions.

\section{Cell culture}

Colon carcinoma (HT-29), colorectal adenocarcinoma (Caco-2), breast ductal carcinoma (T47D), tamoxifen resistant breast ductal carcinoma ( T47D-T.R), and estrogen independent breast carcinoma (MDA-MB468) cell lines were maintained as exponentially growing cultures in RPMI 1640 cell culture medium (PAA, Germany), supplemented with $10 \%$ fetal bovine serum (FBS; Gibco, USA), for HT-29 cells and
15\% FBS for Caco-2 and T47D cells. The Swiss mouse embryo fibroblast (NIH 3T3) cell line was kept in Dulbecco's Modified Eagle's Medium (DMEM; PAA, Germany), supplemented with $10 \%$ FBS. $100 \mathrm{IU} / \mathrm{ml}$ penicillin and $100 \mu \mathrm{g} / \mathrm{ml}$ streptomycin (Roche, Germany) were added to the media. All cell lines were cultured at $37^{\circ} \mathrm{C}$ in air/ carbon dioxide (95:5) atmosphere.

\section{Determination of cell viability by MTT} assay

The concentration of $5,15,45,135,405$, 810 and $1215 \mu \mathrm{g} / \mathrm{ml}$ from all samples, including total methanolic extract and partition fractions, were tested for each cell line. Samples were dissolved in DMSO (Dimethyl Sulfoxide) and further diluted with cell culture medium. The final DMSO concentration used was $1 \%$ of total volume of the medium in all treatments, including the control group. Cells with no treatment and Methotrexate treatment were examined as negative and positive controls, respectively.

For the MTT assay, $1 \times 10^{4}$ cells /wells were plated into 96-well plates (Nunc, Denmark) and incubated for 24 hours before addition of extracts. After 72 hours of incubation for HT-29 cells, 96 hours for T47D and NIH 3T3 cells, 48 hours for T47DT.R and MBA-MD468, as well as 120 hours for Caco-2 cells, $20 \mu \mathrm{L}$ of 3-(4,5D i m e thy $1 \mathrm{th}$ i a z o $1-2-$ y 1$)-2,5$ diphenyltetrazolium bromide (MTT; Merck, Germany), reagent $(5 \mathrm{mg} / \mathrm{ml})$ in phosphate buffered serum (PBS) was added to each well. The plates were allowed to proliferate and their exponential phase of growth. They were then exposed to different treatments with the extracts. The incubation time for each cell line was assigned according to the normal growth curve of that cell line and was determined as twice as long as the doubling time of each cell line. The plates were incubated at $37^{\circ} \mathrm{C}$ for 4 hours. At the end of the incubation period, the medium was removed and $100 \mu \mathrm{l}$ cell DMSO (culture grade) was added to each well. The formazan salts were quantified by reading the absorbance at $550 \mathrm{~nm}$ on a microplate reader (Anthos, Austria). (Mosmann, T. 1983) 
Cell viability in MTT assays was calculated as a percentage of untreated cells (control value). The cytotoxicity value was presented as $\mathrm{IC}_{50}$ (the median growth inhibitory concentration) of the reagents. $\mathrm{IC}_{50}$ values were calculated by Sigmaplot (10) software.

Determination of Drug-Induced Apoptosis by Flow Cytometry

Apoptosis was detected by flow cytometry using Annexin-V-FITC and PI staining. Caco-2 and T47D cells were seeded in 6well plates $\left(5 \times 10^{5}\right.$ Cells/well $)$ in RPMI. Cells were then exposed to different treatments with extracts; at the end of the treatments cells were trypsinized, centrifuged and washed with PBS. Cells were subsequently incubated for 10 minutes at $4^{\circ} \mathrm{C}$ in dark with PI/AnV-FITC fluorescent dyes; results were determined using Partec flowcytometer equipped with Argon laser. 10000 cells were measured for fluorescent intensity in FL1 (FITC) and FL2 (PI) for each assay and were repeated three times. Living cells were Annexin-V-FITC and PI double negative, while late apoptotic and necrotic cells were double positive. Early apoptotic cells were only Annexin-V-FITC positive but early necrotic cells were only PI positive when quadrant analysis of collected data for FL1 vs. FL2 was utilized.

\section{RESULTS}

\section{Cell viability}

Among all methanolic extract and partition fractions of $S$. swartzii, the hexan fraction showed $\mathrm{IC}_{50}$ value $99.9 \pm 19.38 \mu \mathrm{g} / \mathrm{ml}$ against Caco-2 cell line and Methanolic extract of $S$. swartzii exhibited cytotxic activity against T47D ( $\mathrm{IC}_{50} 205.21 \pm 84.1$ $\mu \mathrm{g} / \mathrm{ml}$ ) (Table 1). Additionally, the hexan fraction of $C$. myrica showed cytotoxicity against T47D cell line $\left(\mathrm{IC}_{50} 99.9 \pm 8.11 \mu \mathrm{g} /\right.$ $\mathrm{ml}$ ) (Table 2). Table 3 shows $\mathrm{IC}_{50}$ values of Methanolic extract and fractions of $C$. sinuos against cell lines. $\mathrm{IC}_{50}$ values of the hexan fraction of $C$. myrica against T47DT.R and MBA-MD468 were $143.15 \pm 7.80$ and $56.50 \pm 0.88(\mu \mathrm{g} / \mathrm{ml})$, respectively (Table 4).

\section{Flow Cytometry}

The proportion of apoptotic cells was $2.29 \%$ in control Caco- 2 cells as evaluated by Annexin-V in flow Cytometric study; this value was increased to $4.56 \%$ when cells treated with the hexan fraction of Sargassum swartzii (fig.1). The percence of T47D cells in early apoptotic region was $1.49 \%$ which was incremented to $2.71 \%$ when cells were treated by the hexan fraction of C. myrica (fig. 2).

TABLE 1

$\mathrm{IC}_{50}$ values $(\mu \mathrm{g} / \mathrm{mL})$ of methanolic extract and partition fractions of Sagassum swartzii against tumor and normal cell lines. Results are expressed as mean \pm SD.

\begin{tabular}{lcccc}
\hline Sample & \multicolumn{4}{c}{ Cell Lines $\left(\right.$ MTT assay) ${ }^{\mathrm{a}}$} \\
\hline Hotal methanolic extract & $>1000$ & Caco-2 & T47D & NIH 3T3 \\
Methanol- $\mathrm{H}_{2} \mathrm{O}$ fraction & $>1000$ & $>1000$ & $205.21 \pm 84.1$ & $607.12 \pm 2.81$ \\
Hexan fraction & $211.54 \pm 11.98$ & $99.9 \pm 19.38$ & $853.89 \pm 113.1$ & $>1000$ \\
Chloroform fraction & $446 \pm 18.2$ & $530.64 \pm 120.44$ & $>1000$ & $639.74 \pm 89.93$ \\
Ethylacetate fraction & $>1000$ & $501.18 \pm 23.45$ & $970.95 \pm 112.09$ & $697.91 \pm 24.3$ \\
Methotrexate & $0.23 \pm 0.02$ & $0.32 \pm 0.04$ & $0.16 \pm 0.09$ & $0.24 \pm 0.013$ \\
\hline
\end{tabular}

${ }^{a}$ Key to cell lines employed: HT-29 and Caco-2 (colon adenocarcinoma), T47D (breast carcinoma), NIH 3 T3 (Swiss embryo fibroblast). 
TABLE 2

$\mathrm{IC}_{50}$ values $(\mu \mathrm{g} / \mathrm{mL})$ of methanolic extract and partition fractions of Cystoseira myrica against tumor and normal cell lines. Results are expressed as mean $\pm \mathrm{SD}$.

\begin{tabular}{lcccc}
\hline Sample & \multicolumn{4}{c}{ Cell Lines (MTT assay)a } \\
\cline { 2 - 5 } & HT-29 & Caco-2 & T47D & NIH 3T3 \\
\hline Total methanolic extract & $>1000$ & $>1000$ & $>1000$ & $>1000$ \\
Methanol-H, ${ }_{2}$ O fraction & $>1000$ & $>1000$ & $381.59 \pm 27.8$ & $>1000$ \\
Hexan fraction & $328.7 \pm 61.28$ & $254.92 \pm 14.91$ & $99.9 \pm 8.11$ & $180.7 \pm 32.8$ \\
Chloroform fraction & $>1000$ & $>1000$ & $165.43 \pm 12.6$ & $739.6 \pm 49.9$ \\
Ethylacetate fraction & $473 \pm 85.4$ & $541.2 \pm 11.6$ & $453.52 \pm 111.1$ & $453.52 \pm 39.8$ \\
\hline
\end{tabular}

a Key to cell lines employed: HT-29 and Caco-2 (colon adenocarcinoma), T47D (breast carcinoma), NIH 3T3 (Swiss embryo fibroblast).

TABLE 3

$\mathrm{IC}_{50}$ values $(\mu \mathrm{g} / \mathrm{mL})$ of methanolic extract and partition fractions of Colpomenia sinuosa against tumor and normal cell lines. Results are expressed as mean \pm SD.

\begin{tabular}{|c|c|c|c|c|}
\hline \multirow[t]{2}{*}{ Sample } & \multicolumn{4}{|c|}{ Cell Lines (MTT assay) ${ }^{\mathrm{a}}$} \\
\hline & НТ-29 & Caco-2 & T47D & NIH $3 \mathrm{~T} 3$ \\
\hline Total methanolic extract & $>1000$ & $>1000$ & $>1000$ & $>1000$ \\
\hline Methanol- $\mathrm{H}_{2} \mathrm{O}$ fraction & $>1000$ & $>1000$ & $>1000$ & $>1000$ \\
\hline Hexan fraction & $>1000$ & $501.65 \pm 27.98$ & $494.03 \pm 17.6$ & $829.47 \pm 43.01$ \\
\hline Chloroform fraction & $771.97 \pm 65.19$ & $>1000$ & $877.8 \pm 134.1$ & $>1000$ \\
\hline Ethylacetate fraction & $>1000$ & $>1000$ & $>1000$ & $943 \pm 123$ \\
\hline
\end{tabular}

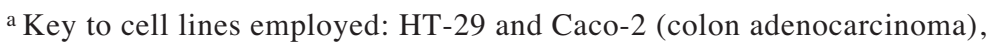
T47D (breast carcinoma), NIH 3 T3 (Swiss embryo fibroblast).

TABLE 4

$\mathrm{IC}_{50}$ values $(\mu \mathrm{g} / \mathrm{mL})$ of Hexan fraction of Cystoseira myrica against tumor cell lines. Results are expressed as mean $\pm \mathrm{SD}$.

Sample Cell Lines (MTT assay) ${ }^{\mathrm{a}}$

T47D T47D-T.R

MDA-MB468

Cystoseira myrica

$99.9 \pm 8.11$

$143.15 \pm 7.80$ $56.50 \pm 0.88$

a Key to cell lines employed: T47D-T.R (T47D breast carcinoma tamoxifen resistant); MDA-MB468 (breast carcinoma estrogen receptor independent). 


\section{DISCUSSION}

The cytotoxicity of natural products is based on the presence of antitumor metabolites. Bioactive cytotoxic compounds have been found in marine algae. Several sulfated polysaccharides separated from algae have shown antitumor, anticancer, antimetastatic activities in mice (Coombe et al., 1987). Antitumor activity has also been noted with the macro algae Sargassum stenophyllum (Dias et al., 2005). In addition, the hydroquinone diterpen from
Cystoseira mediterraneol has been shown tp have an inhibitory effect on mitotic cell division (Francisco et al., 1985).

In this study, methanolic extract of $S$. swartzii was the only species of the three species of brown algae collected in the Persian Gulf with cytotoxic effect against T47D cells, indicating selective cytotoxic compounds in this extract. The hexansoluble fraction of $S$. swartzii was more effective against Caco- 2 cells than were the other fractions. This result is comparable to those of another cytotoxic study of $S$.
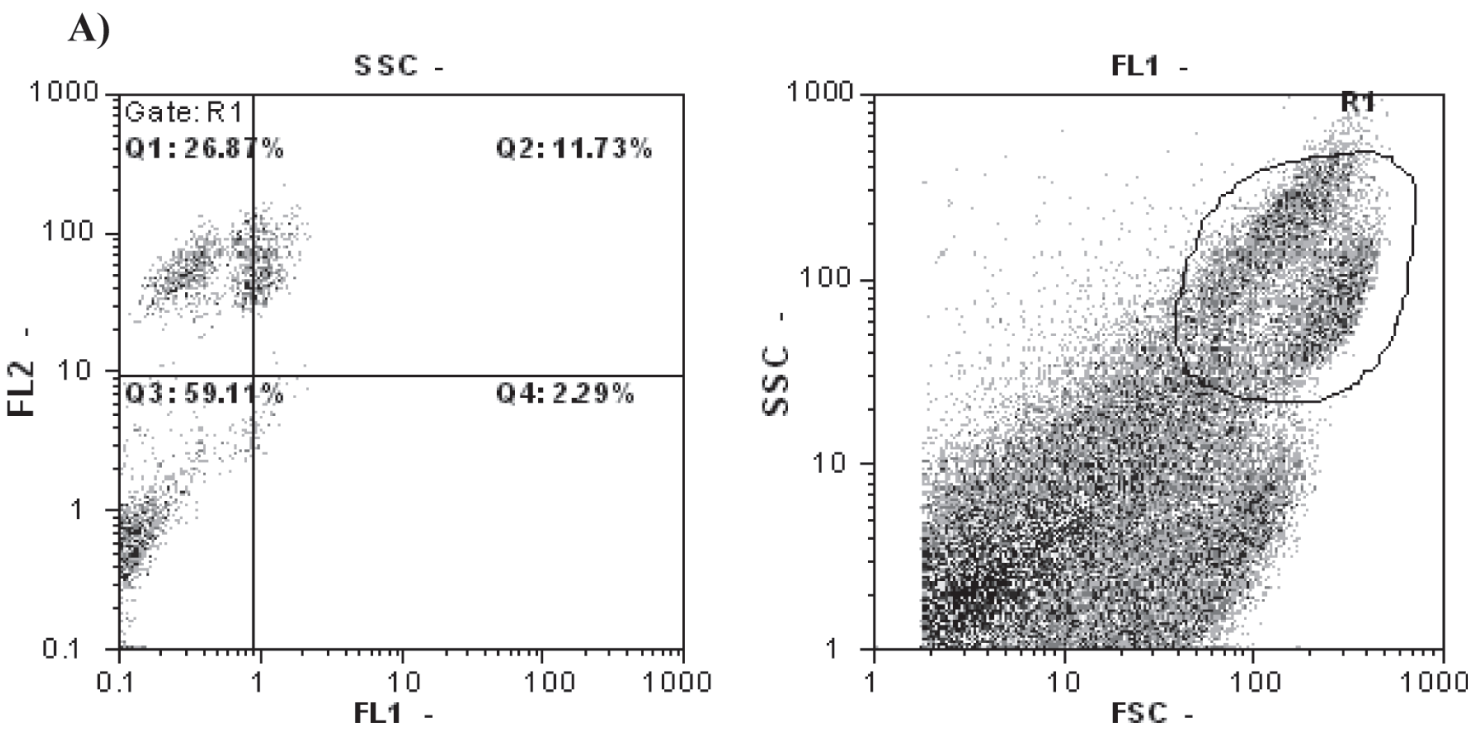

B)
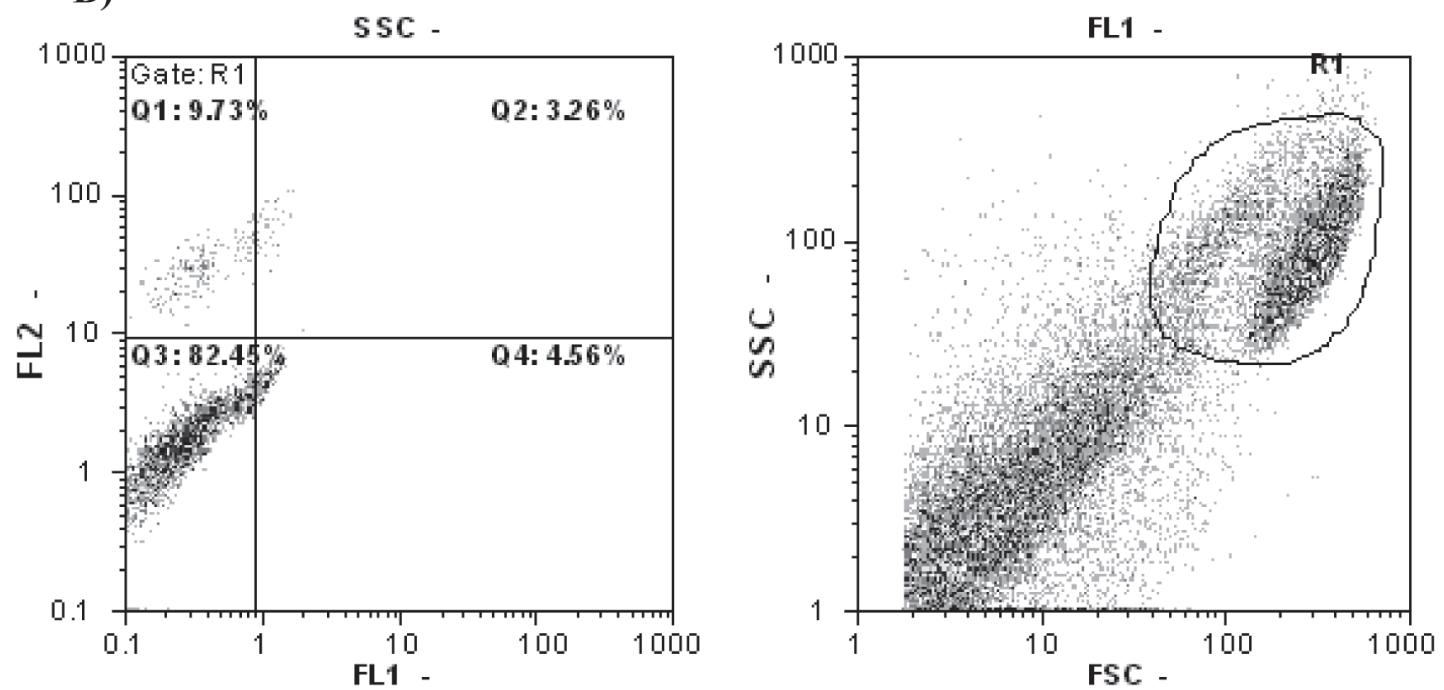

Figure 1: The proportion of apoptotic Caco-2 cells evaluated by Annexin-V in flowcytometry study; A) Control Caco-2 cells B) Cells treated with Hexan fraction of Sargassum swartzii. 
swartzii on Artemia salina (Brine Shrimp) (Ara et al., 1999). In that study, the hexan fraction of the aforementioned alga showed a potent cytotoxic effect on Artemia salina. This may be due to a non-polar structure of cytotoxic compound(s). The hexan fraction of Cystoseira myrica also exhibited cytotoxic effects toward T47D cell line. Alcohol extract and six hydroazolen diterpenes of $C$. myrica collected at ElZafrana in the Gulf of Suez showed inhibition activities against NIH 3T3, SSVNIH 3T3 and KA3IT (Ayyad et al.,
2003), although with lower $\mathrm{IC}_{50}$ values than those in our study. The results of these 2 studies represent the various activities of the same alga living in different environments. This study did not note any significant cytotoxic activities for total extract and fractions of Colpomenia sinuosa. The $\mathrm{IC}_{50} \mathrm{~S}$ of all extracts and fractions are greater than that of methotrexate as a positive control.

In order to investigate the potential cytotoxic effects of extracts on hormone dependent and independent breast carcinoma cells, the cytotoxic properties of the hexan
A)

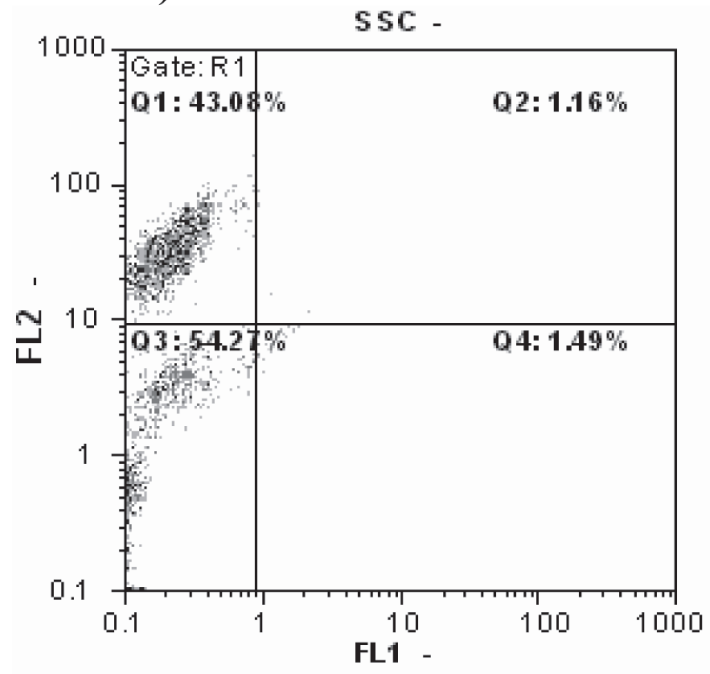

B)

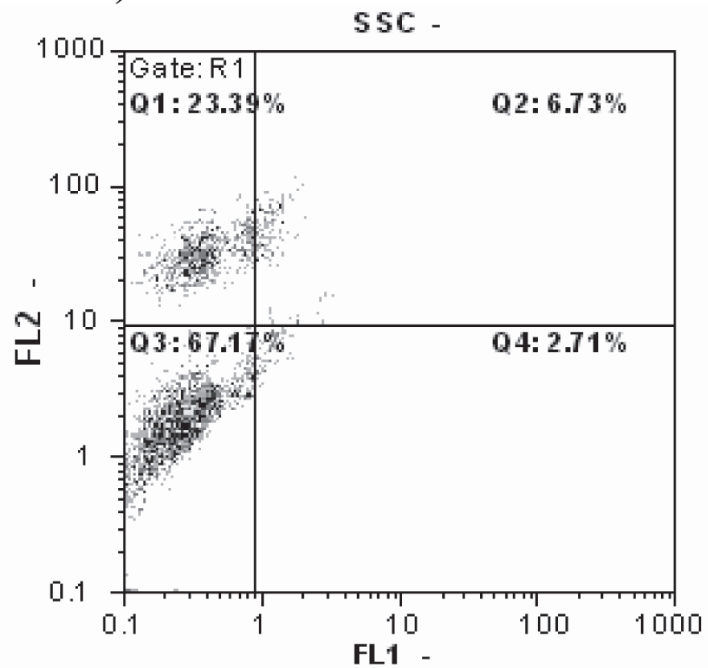

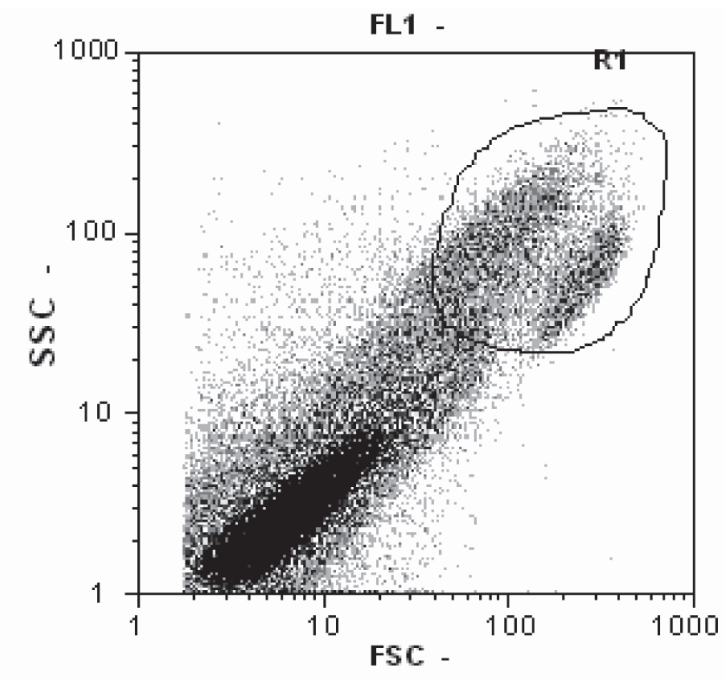

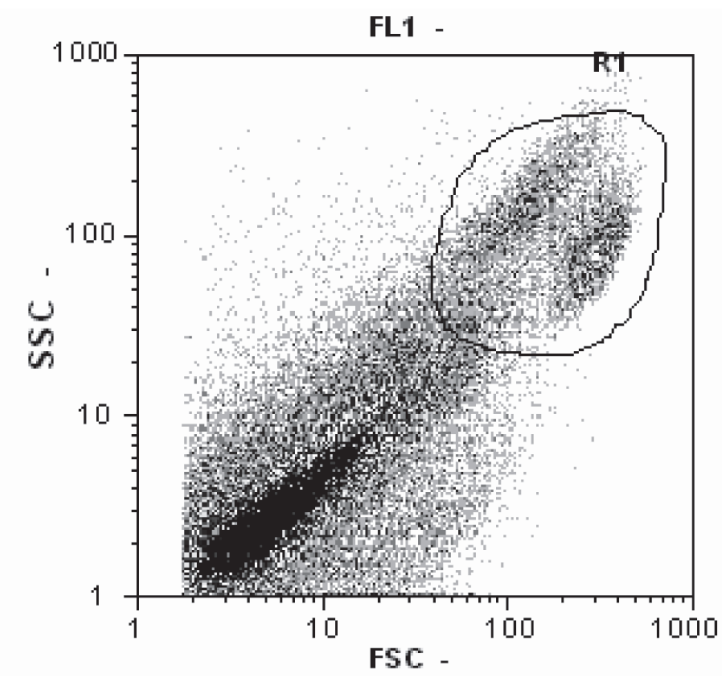

Figure 2: The proportion of apoptotic T47D cells evaluated by Annexin-V in flowcytometry study; A) Control T47D cells B) Cells treated with Hexan fraction of Cystoseira myrica. 
fraction of $C$. myrica were evaluated in both T47D (estrogen receptor positive) and MDAMB486 cells (estrogen receptor negative). We found that MDA-MB468 cells were more sensitive than T47D cells. This reflects an estrogen receptor independent mechanism for cytotoxixity of the extract in breast cancer cells. To compare the rate of cytotoxicity in multiple drug resistance protein (MDR) positive and negative cells, the MTT assays for T47D cells and T47D-T.R cells were completed and reported in our previous study on this subject, which showed a higher level of MDR-1 expression (Bazargan et al, 2008; Ostad et al, 2009). We observed T47D parent cells to be more vulnerable to cytotoxic properties of the hexan fraction of $C$. myrica, which recommends a role for the MDR-1 in the development of possible future tolerance to the extract.

The potential apoptotic properties of the extracts were also investigated in this study. It was noted that the hexan fraction of both $S$. swartzii and $C$. myrica increased the percentage of apoptotic cells among $\mathrm{Caco} 2$ and T47D cells, respectively This suggests an apoptotic pathway for the mechanism of cytotoxicity of the extracts and demands further evaluation for clarification of the potential apoptotic pathway. The caspase proteins are among the candidate proteins to be considered in future studies.

Isolation and characterization of the hexan fractions of $S$. swartzii and $C$. myrica, as well as investigation of specific cytotoxic pathway(s) may help to determine if the extract is valuable for its antineoplastic effects.

\section{ACKNOWLEDMENT}

This research was supported by grants (No: 425.575) of the Pharmaceutical Science Research Center, Tehran University of Medical science.

\section{REFERENCES}

ABOURRICHE A, CHARROUF M, BERRADA M, BENNAMARA A, CHAIB N, FRANCISCO C (1999) Antimicrobial activities and cytotoxicity of the brown algae Cystoseira tamariscifolia. Fitoter 70: 611-614
AMICO V (1995) Marine brown algae family Cystoseiraceae: Chemistry and taxonomy. Phytochem 39: $1257-1279$

ARA J, SULTANA V, EHTESHAMUL-HAQUE S, QASIM R, AND AHMAD VU (1999) Cytotoxic activities of marine macro-algae on artemia salina (Brine Shrimp). Phytother Res 13: 304-307

AYYAD SN, ABDEL-HALIM OB, SHIER W T, AND HOYE T R (2003) Cytotoxic hydroazulen diterpenes from the brown alga Cystoseira myrica. Z.Natureforsch 58: $33-38$

BAZARGAN S, FOULADDEL S, SHAFIEE A, AMINI M, GHAFFARI SM, AZIZI E (2008) Evaluation of anticancer effects of newly synthesized dihydropyridine derivatives in comparision to verapamil and doxorubicin on $\mathrm{T} 47 \mathrm{D}$ parental and resistant cell lines in vitro. Cell Biology and Toxicology 24(2): 165-174

BENNAMARA A, ABOURRICHE A, BERRADA M, CHARROUF M, CHAIB N, BOUDOUMA M, GARNEAU FX (1999) methoxybifurcarenone: an antifungal and antibacterial meroditerpenoid from the brown alga Cystoseira tamariscifolia. Phytochem 52: $37-40$

COOMBE DR, PARISH CR, RAMSHAW IE, SNOWDEN JM (1987) Analysis of the inhibition of tumor metastasis by sulfate polysaccharides. Int J Cancer 39: 82-88

DIAS PF, SIQUEIRA JR JM, VENDRUSCOLO LF, NEIVA TDJ, GAGLIARDI AR, MARASHIN M, AND RIBEIRO-DO-VALLE RM (2005) Antiangiogenic and antitumoral properties of a polysaccharide isolated from the seaweed Sargassum stenophyllum. Cancer Chemother Pharmacol 56: 436-446

FRANCISCO C, BANAIGS B, VALLS R, CODOMIER L (1985) Mediterraneol, a novel rearranged diterpenoidhydroquinon from the marine alga Cystoseira mediterranea. Tetrahedron Lett 26: 2629-2632

MAYER A M S, RODRIGUEZ A D, BERLINCK R G S, HAMANN M T (2007) Marine pharmacology in 20034. Comparative Biochemistry and Physiology 145: 553581

MORI J, IWASHIMA M, WAKASUGI $\mathrm{H}$, SAITO $\mathrm{H}$, MATSUNAGA T, OGASAWARA M, ET AL. (2005) New plastoquinones isolated from the brown alga, Sargassum micracanthum. Chem Pharm Bull 53: 11591163

MOSMANN T (1983) Rapid colorimetric assay for cellular growth and survival:application to proliferation and cytotoxicity assays. J Immunol Methods 65: 55-63

NUMATA A, KANBARA S, TAKAHASHI C, FUJIKI R, YONEDA M, FUJITA E, NABESHIMA Y (1991) Cytotoxic activity of marine algae and a cytotoxic principle of the brown alga Sargassum tortile. Pharmaceutical Society of Japan 39: 2129-2131

OSTAD SN, MANESHI A, SHARIFZADEH M, AZIZI E (2009) Effect of 17- $\square \leq$ estradiol on the expression of inducible nitric oxide synthase in parent and tamoxifen resistant T47D breast cancer cells. IJPR 8(2): 125-133

SOHRABIPOUR J AND RABII R (1999) A list of marine algae of sea shores of the Persian Gulf and Oman Sea in the Hormozgan province. Iran Jour Bot 8: 131- 162

SOHRABIPUOR J, NEJADSATARI T, ASSADI M, AND RABEI R (2004) The marine algae of the southern coast of Iran, Persian Gulf, Lengeh area. Iran Journ Bot 10: 83-93

TANG H-F, YI Y-H, YAO X-S, XU Q-Z, ZHANG S-Y, LIN H-W (2002) Bioactive steroids from the brown alga Sargassum caryophyllum. J Asian Nat Product Res 4: $95-105$ 
